\title{
Association Between PON1 L55M Polymorphism and PON1 Enzyme Activity in Patients with Leukemia
}

\author{
Nazan ERAS ${ }^{1}$, Anil TOMBAK ${ }^{2}$, Naci TIFTIK ${ }^{2}$, Serap YALIN ${ }^{3}$, Mehmet BERKOZ ${ }^{4}$, \\ Seval KUL ${ }^{5}$, Etem AKBAS $^{6}$ \\ ${ }^{1}$ Mersin University, Faculty of Medicine, Department of Medical Genetics, Mersin \\ ${ }^{2}$ Mersin University, Faculty of Medicine, Department of Hematology, Mersin \\ ${ }^{3}$ Mersin University, Faculty of Pharmacy, Department of Biochemistry, Mersin \\ ${ }^{4}$ Yuzuncu Yil University, Faculty of Pharmacy, Department of Pharmaceutical Technology, Van \\ ${ }^{5}$ Gaziantep University, Faculty of Medicine, Department of Biostatistics, Gaziantep, \\ ${ }^{6}$ Mersin University, Faculty of Medicine, Department of Medical Biology, Mersin, TURKEY
}

\begin{abstract}
Paraoxonase 1 (PON1) is an important antioxidant enzyme which has a role in preventing the effects of systemic oxidative stress. The purpose of our study was to investigate the possible association between PON1 L55M polymorphism and leukemia development and to determine the relationship between PON1 genotypes and PON1 enzyme activities. Genotypes of 102 cases and 112 healthy controls were determined by PCR-RFLP. PON1 enzyme activity was determined according to Eckerson's method. The ratio of MM genotype belonging to PON1 L55M polymorphism in control group was $6.3 \%$ and was $7.8 \%$ in patients with leukemia $(p=0.39)$. PON1 enzyme activity was $118.8 \pm 115.1 \mathrm{U} / \mathrm{mL}$ in control group, while decreased to $75.6 \pm 64.4 \mathrm{U} / \mathrm{mL}$ in patients with leukemia $(p=$ 0.004). PON1 enzyme activities of the individuals with MM genotypes belonging to PON1 L55M polymorphism was $57.43 \pm 21.61 \mathrm{U} /$ $\mathrm{mL}$ in control group and decreased to $39.18 \pm 45.61 \mathrm{U} / \mathrm{mL}$ in leukemic patients. Our results suggest that, PON1 L55M polymorphism genotype ratios do not affect leukemia development. However, reduced PON1 enzyme activity and also the combination of PON1 L55M polymorphism with reduced PON1 enzyme activity are associated with the increased risk of leukemia. Furthermore, older age may be a risk factor for developing leukemia.
\end{abstract}

Keywords: Antioxidant, Leukemia, Oxidative stress, Paraoxonase (PON), Polymorphism

ÖZET

Lösemi Hastalarında PON1 L55M Polimorfizmi ile PON1 Enzim Aktivitesi Arasındaki İlişki

Paraoksonaz 1 (PON1), sistemik oksidatif stresin etkilerini önlemede rol oynayan önemli bir antioksidan enzimdir. Çalışmamızın amacı, PON1 L55M polimorfizmi ve lösemi gelişimi arasındaki olası ilişkiyi araştırmak ve PON1 genotipleri ile PON1 enzim aktiviteleri arasındaki ilişkiyi saptamaktır. Lösemi tanısı almış 102 hasta birey ve 112 sağlıklı kontrol grubunun genotipleri PCR-RFLP yöntemi ile belirlendi. PON1 enzim aktivitesi Eckerson yöntemi ile ölçüldü. PON1 L55M polimorfizmine ait MM genotip oranları kontrol grubunda \%6.3 iken lösemili hastalarda \% 7.8 idi $(\mathrm{p}=0.39)$. PON1 enzim aktivitesi kontrol grubunda $118.8 \pm 115.1 \mathrm{U} / \mathrm{mL}$ iken lösemili hastalarda düşük olarak saptandı $(75.6 \pm 64.4 \mathrm{U} / \mathrm{mL}, \quad \mathrm{p}=0.004)$. PON1 L55M polimorfizmine ait MM genotipli bireylerin PON1 enzim aktivitesi kontrol grubunda $57.43 \pm 21.61 \mathrm{U} / \mathrm{mL}$ iken lösemili hastalarda düşük olarak saptandı (39.18 $\pm 45.61 \mathrm{U} / \mathrm{mL})$. Bizim bulgularımı PON1 L55M polimorfizmi genotip oranlarının lösemi gelişimini etkilemediğini göstermektedir. Bununla birlikte, düşük PON1 enzim aktivitesi tek başına ve PON1 L55M polimorfizmi ile birlikte lösemi riski artışı ile ilişkilidir. Ayrıca ileri yaş lösemiye yakalanma olasılığını yükseltir.

Anahtar Kelimeler: Antioksidan, Lösemi, Oksidatif stres, Paraoksonaz (PON), Polimorfizm 


\section{INTRODUCTION}

Leukemia is a multifactorial disease, infectious, genetic, physical and chemical factors are all involved in the pathogenesis of leukemia. ${ }^{1}$ Among environmental chemicals, pesticides are categorized according to their biological mechanisms (e.g. insecticides, fungicides, herbicides, rodenticides, fumigants). ${ }^{2}$ Insecticides containing organophosphates cause prolonged inhibition of acetylcholinesterase, resulting in chronic harmful effects on human health (e.g. neuropsychological disorders, disruption of the endocrine system, developmental anomalies, hypersensitivity, disorders of the immune system and cancer development). ${ }^{3}$

Paraoxonase (aryldialkylphosphatase, EC 3.1.8.1) is a calcium-dependent enzyme and possess the activities of organophosphatase, arylesterase and lactonase. It hydrolyzes organophosphorus insecticides (e.g. paraoxon, chlorpyrifos-oxon, diazoxon), nerve agents (e.g. sarin, soman), and thus protects against the organophosphorus compound poisoning. ${ }^{4}$

Oxidative stress is defined as a redox imbalance between pro-oxidant and antioxidant systems with either an overproduction of oxidants or a deficiency of antioxidant agents. ${ }^{5}$ Under oxidative stress, excessive reactive oxygen species (ROS) can cause damage to many cellular and extracellular constituents, including DNA, proteins and lipids. ${ }^{6}$ The physiological role of the PON is not exactly known; however, increasing evidence indicates that PON can offer protection against oxidative damage by hydrolysing lipid hydroperoxides and by protecting the low-density lipoproteins from oxidative modifications. ${ }^{7,8} \mathrm{PON}$ also has peroxidase-like activity; can hydrolyse hydrogen peroxide, which is one of the major ROS produced by the arterial wall during atherogenesis. ${ }^{9}$

The gene coding human PON1 enzyme is located on the long arm of chromosome 7 between q21.3 and $\mathrm{q} 22.1 .{ }^{10}$ The PON1 gene has two common polymorphisms in the coding region: a leucine (L) to methionine (M) substitution at position 55 (L55M) and a glutamine $(\mathrm{Q})$ to arginine $(\mathrm{R})$ substitution at position 192 (Q192R). ${ }^{11}$ L55M [rs854560] and Q192R [rs662] polymorphisms affect serum concentrations and activities of PON1. ${ }^{12}$ It was sug- gested that PON1-55M allele could have correlated with higher PON1 activity than PON1-55L allele. ${ }^{13}$ In another study, it was observed that the differences in the serum levels of PON1 linked to the L54M polymorphism were due to the reduced stability of the PON1-55M protein. ${ }^{14}$ Reduced PON1 activities were shown in high oxidative stress diseases such as coronary heart disease ${ }^{15}$, hypercholesterolemia $^{16}$, diabetes mellitus ${ }^{17}$, and celiac disease. ${ }^{18}$ In recent years, number of the studies investigating the relation between PON1 activity and cancer are increasing. Compared to the healthy controls, lower serum levels of PON1 were measured in patients suffering from breast ${ }^{19,20}$, lung $^{20,21}$, laryngeal ${ }^{22}$, gastric $^{23}$, pancreatic ${ }^{24}$ and colorectal cancer. ${ }^{20}$

Variations due to the presence of single nucleotide polymorphisms in antioxidant enzymes may contribute to the inter-individual differences between the transcript levels and enzyme activities, which might play a significant role in the development of cancer. Therefore, the aim of this study was to investigate the relation between PON1 genotypes and PON1 enzyme activities in patients with acute and chronic leukemias.

\section{PATIENTS AND METHODS}

The case group consisted of 102 patients (32 ALL, 32 AML, 17 CLL, and 21 CML) (mean age: $51.3 \pm$ 15.2; 50 female and 52 male) who had been newly diagnosed with leukemia at the Department of Hematology, Mersin University Faculty of Medicine, Turkey. The control group consisted of 112 persons (mean age: $49.3 \pm 12.8 ; 52$ females and 60 males) who were randomly selected from healthy individuals residing in Mersin City. Control group consists of healthy people that were similar to patient group in age and gender distributions. Control subjects also did not have a positive family history of leukemia. Interview response-rates among eligible case and control participants were $96.1 \%$ and $98.2 \%$, respectively. The study protocol was approved by the Local Ethics Committee of Mersin University Faculty of Medicine. All participants were informed for the aim and design of the study. 


\section{Genotype Analysis}

Venous blood $(8 \mathrm{~mL})$ from each subject was collected into the tubes containing $50 \mathrm{mmol} / \mathrm{L}$ disodium-EDTA, and genomic DNA was extracted using with the standard phenol/chloroform-based method. PON1 L55M polymorphism was analysed by PCR-RFLP. In order to avoid potential contamination, the PCR assays were performed with at least one known DNA genotype (positive control) and one negative control (without DNA template). PCR amplification was amplified using forward 5'GAAGAGTGATGTATAGCCCCAG3' and reverse 5'TTTAATCCAGAGCTAATGAAAGCC3' primers. ${ }^{25}$ The PCR mixture contained 50 ng of genomic DNA, 50 pmol of each primer, 200 $\mu \mathrm{M}$ of dNTPs, $1 \times$ PCR buffer with (NH4)2SO4, 2 $\mathrm{mM} \mathrm{MgCl}$, and 2.0 units of Taq DNA polymerase (MBI Fermentas, Vilnius, Lithuania) with a final volume of $50 \mu \mathrm{L}$. Amplification was carried out in a TC-512 Thermal Cycler (Techne), and the cycling conditions were; $95^{\circ} \mathrm{C}$ for $9 \mathrm{~min}, 35$ cycles of $95^{\circ} \mathrm{C}$ for $1 \mathrm{~min}, 60^{\circ} \mathrm{C}$ for $1 \mathrm{~min}, 72^{\circ} \mathrm{C}$ for $1 \mathrm{~min}$, and a final extension at $72^{\circ} \mathrm{C}$ for 10 min. ${ }^{25} \mathrm{PCR}$ amplified DNA fragments were digested with $10 \mathrm{U}$ Hsp92II (Promega, Southampton, UK) at $37^{\circ} \mathrm{C}$ for $16 \mathrm{~h}$ and analyzed following the electrophoresis in $3 \%$ agarose gel stained with ethidiumbromide $(0.5$ $\mu \mathrm{g} / \mathrm{mL}$ ). The L allele (wild-type) produced an undigested product of $170 \mathrm{bp}$, whereas $\mathrm{M}$ allele produced two products: $126 \mathrm{bp}$ and $44 \mathrm{bp}$. Genotyping was performed blindly with respect to case/control status and repeated twice for all subjects, but no discordant genotype classifications were identified.

\section{Plasma Samples}

Venous blood samples of the cases were collected in (1000 IU) heparin containing tubes and centrifuged at $1000 \mathrm{x}$ g for 10 minutes at $4^{\circ} \mathrm{C}$, the supernatant plasma is aspirated, transferred to a polypropylene tube and fresh plasma samples were stored at $-80^{\circ} \mathrm{C}$ until analysis.

\section{Analysis of PON1 Activity}

PON1 enzyme activity was measured by using paraoxon as substrate. ${ }^{26}$ The basal assay mixture included $100 \mathrm{mM}$ Tris- $\mathrm{HCl}, 2 \mathrm{mM} \mathrm{CaCl}{ }_{2}$, and 4 $\mathrm{Mm}$ paraoxon. The rate of paraoxon hydrolysis (diethyl-p-nitrophenylphosphate) was evaluated by monitoring an increase in absorbance at $412 \mathrm{~nm}$ at $37^{\circ} \mathrm{C}$. The amount of generated p-nitrophenol was calculated from the molar absorptivity coefficient of $18290 \mathrm{M}-1 \mathrm{~cm}-1$. PON1 enzyme activity is expressed as $\mathrm{U} / \mathrm{mL}$ of plasma.

\section{Statistical Analysis}

Selected characteristics were compared between cases and controls by using the student's t-test for continuous variables and the chi-square test for categorical variables. Allele and genotype frequencies among cases and controls were calculated and deviation from Hardy-Weinberg equilibrium was examined by the chi-square test. We calculated odds ratios and $95 \%$ confidence intervals by using unconditional binary logistic regression. Mann Whitney-U test was used to assess the differences of PON1 levels according to the genotypes between the patient and control group. Results are reported as the mean $\pm \mathrm{SD}$. The analyses of data were performed by use of the computer software SPSS for Windows, version 11.5. P value less than 0.05 was accepted as statistically significant. Leukemia patients are analyzed with respect to age groups and their ratios in Mersin sample using Kruskal Wallis test. The total Mersin population is 1.727.255.

\section{RESULTS}

Demographic characteristics and frequencies of alleles/genotypes of PON1 L55M polymorphism of the patients with leukemia and healthy control subjects were represented in Table 1. The mean age of the patient group was slightly higher compared with the control group; 51.3 years versus 49.3 years, respectively. Distribution of gender was similar in both groups $(\mathrm{p}=0.81)$. The frequency of $\mathrm{M}$ allele was slightly higher in patients (34.8\%) than in controls $(28.6 \%)$, but this difference was not statistically significant ( $\mathrm{p}=0.17$ ). The frequencies of the LL, LM and MM genotypes in patients were $38.2 \%, 53.9 \%$ and $7.8 \%$, respectively and $49.1 \%, 44.6 \%$ and $6.3 \%$ in controls, respectively. Since the LL genotype is hypothesized to have the lowest leukemia risk, it was chosen as the reference category. Compared with the LL genotype, 


\begin{tabular}{|c|c|c|c|}
\hline & $\begin{array}{l}\text { Patients } \\
\mathrm{n}(\%)\end{array}$ & $\begin{array}{l}\text { Controls } \\
\mathrm{n}(\%)\end{array}$ & P-value \\
\hline \multicolumn{4}{|l|}{ Age } \\
\hline Mean \pm SD & $51.3 \pm 15.2$ & $49.3 \pm 12.8$ & $0.315^{\star}$ \\
\hline \multicolumn{4}{|l|}{ Gender } \\
\hline Male & $52(50.9)$ & $60(53.6)$ & $0.81^{* \star}$ \\
\hline Female & $50(49.1)$ & $52(46.4)$ & - \\
\hline \multicolumn{4}{|c|}{ Genotype frequencies } \\
\hline LL & 39 (38.2) & 55 (49.1) & - \\
\hline LM & 55 (53.9) & $50(44.6)$ & $0.12 \ddagger$ \\
\hline MM & $8(7.8)$ & $7(6.3)$ & $0.39 \ddagger$ \\
\hline $\mathrm{LM}+\mathrm{MM}$ & $63(61.7)$ & $57(50.9)$ & $0.12 \ddagger$ \\
\hline \multicolumn{4}{|c|}{ Allele frequencies } \\
\hline L & $133(65.2)$ & $160(71.4)$ & - \\
\hline M & $71(34.8)$ & $64(28.6)$ & $0.17 \ddagger$ \\
\hline \multicolumn{4}{|c|}{$\begin{array}{l}{ }^{\star} \text { From Student } t \text { test } \\
\text { ** From Chi-square test } \\
\ddagger \text { From unconditional binary logistic regression analysis }\end{array}$} \\
\hline
\end{tabular}

OR values for $\mathrm{LM}$ and $\mathrm{MM}$ genotypes were 1.55 (95\% CI, 0.88-2.71) and 1.61 (95\%CI, 0.54-4.81), respectively. When we compared the sum of LM and MM genotypes with LL genotype, no association was found between the genotype and leukemia $(p=0.12)$. PON1 genotype frequencies were in Hardy-Weinberg equilibrium in the control group $(p=0.321)$, but not in the patient group $(p=0.003)$.

It is known that ALL is a type of leukemia observed in young people. In our sample group there are 32 ALL patients and the average age of this sample group is $22.3 \pm 22.9$. The average age of the sample group that contains AML, KML and KLL patients is $50.4 \pm 16$. ALL patients are younger than other leukemia groups $(p<0.001)$. It is observed in Figure 1 (blue line) that there is no relation between age and having leukemia risk in all types of leukemia except ALL (Table 2, column 1) ( $\mathrm{p}>0.05$ ). Because the number of patients in age groups are not equal, the number of patients decreases in older age groups (Table 2, column 1). In Table 2 (col- umn 3), it is clearly shown that ratio of leukemia patients increases with age (Figure 1, red line) $(\mathrm{p}<$ $0.001)$.

The mean PON1 activities were $75.6 \pm 64.4 \mathrm{U} / \mathrm{mL}$ and $118.8 \pm 115.1 \mathrm{U} / \mathrm{mL}$ in the patient and control group, respectively which was statistically significant $(\mathrm{p}=0.004)$. We also investigated the relation between PON1 genotypes and PON1 enzyme activities. Accordingly PON1 L55M genotypes, PON1 activity was higher in LL, intermediate in LM, and lower in MM genotypes in both control and patient groups. PON1 activities for all genotypes decreased in the patient group compared with the control group, but patients with MM genotype showed significantly lower PON1 activity than the controls with MM genotype $(\mathrm{p}=0.028)$. Likewise, when LM and MM genotypes considered together, PON1 activities were lower in patients with leukemia $(70.38 \pm 59.37 \mathrm{U} / \mathrm{mL})$ compared to the control group $(110.74 \pm 118.00 \mathrm{U} / \mathrm{mL})(\mathrm{p}=0.028)($ Table $3)$. 


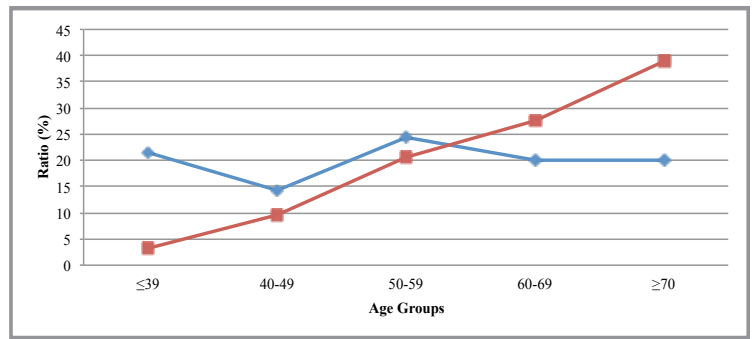

Figure 1. Blue line: distribution of ratio of leukemia patients except ALL with respect to age, red line: distribution of ratio of leukemia patients except ALL with respect to age in Mersin sample.

\section{DISCUSSION}

The main goals of this study were to describe the genotype and the allele frequencies of PON1 L55M polymorphism and to assess the effect of genotype on PON1 enzyme activity in Turkish leukemia patients. In order to analyze the relation between leukemia and age, age distribution of the sampling population and the ratio of leukemia patients in this sampling population should be considered. Within this context, it is observed that the ratio of leukemia increases with advancing age in case group excluding ALL. Similar to other types of cancer, leukemia is also an older-age disease.

PON1 has anti-inflammatory and antioxidant properties. Many studies have been conducted to find relations between the PON1 L55M polymorphism and various diseases including diabetes mellitus ${ }^{27}$, ovarian cancer $^{28}$, migraine ${ }^{29}$, breast cancer ${ }^{30-32}$, prostate cancer $^{33}$, childhood acute leukemia ${ }^{34}$, and non-insulin dependent diabetes mellitus. ${ }^{35}$ One study was performed on 100 patients with type 2 di- abetes mellitus and was found no relation between PON1 LM 55 polymorphism and type 2 diabetes mellitus. ${ }^{27}$ Furthermore, Agachan et al. found that PON 55 genotype distribution was similar in patients with non-insulin dependent diabetes mellitus and controls. ${ }^{35}$ In another study, although it was not statistically significant $(p>0.05)$, it was found that the MM genotype frequency was higher in ovarian cancer patients than the controls. ${ }^{28}$ In addition, Yildırım et. al not observed a significantly different proportion of MM genotype distribution between patients with migraine and controls. ${ }^{29}$ Several studies conducted at different localities in Turkey showed that no significant differences in genotype distributions among the cases and controls, ${ }^{27-29,35}$ and these results were similar to those of our study. In order to evaluate the possible influence of the PON1 L55M polymorphism on leukemia risk, we performed a case-control study in Mersin, Turkey. To the best of our knowledge, only one paper was published investigating the PON1 polymorphism in leukaemia. Accordingly PON1 L55M polymorphism was associated with an increased risk of developing childhood leukemia (LM + MM, OR 1.93, 95\%CI 1.32-2.81). ${ }^{34}$ Moreover, some researchers observed an increased risk associated with the MM genotype for breast ${ }^{30-32}$, and prostate cancer. ${ }^{33}$ Similarly, within the meta-analysis of 21 case-control studies involving 5.627 cases and 6.390 controls, it was observed that PON1 L55M polymorphism was associated with an increased risk for breast, prostate, and ovarian cancer. ${ }^{36} \mathrm{~A}$ meta-analysis conducted in 2017, which included twenty-one independent case-control studies,

\begin{tabular}{|llll|}
\hline \multicolumn{4}{|l|}{ Table 2. Age distribution of leukemia patients except ALL in Mersin sample } \\
\hline Age Group & $\begin{array}{l}\text { Leukemia Patients } \\
\text { except ALL } \\
\mathrm{n}=70 \quad(\%)\end{array}$ & $\begin{array}{l}\text { Age distribution of } \\
\text { Mersin sample } \\
\mathrm{n}=1.727 .255 \quad(\%)\end{array}$ & $\begin{array}{l}\text { Age distribution of Leukemia } \\
\text { patients except ALL in Mersin sample } \\
(\%)\end{array}$ \\
\hline$\leq 39$ & $15(21.42)$ & $1.088 .496(63.01)$ & 3.23 \\
$0-49$ & $10(14.28)$ & $241.593(13.98)$ & 9.72 \\
$50-59$ & $17(24.28)$ & $194.226(11.24)$ & 20.50 \\
$60-69$ & $14(20.0)$ & $118.673(6.87)$ & 27.62 \\
$\geq 70$ & $14(20.0)$ & $84.267(4.87)$ & 38.90 \\
\hline
\end{tabular}


Table 3. Findings of PON1 genotypes and PON1 activity $(\mathrm{U} / \mathrm{mL})$ in patient and control groups.

\begin{tabular}{|lccccc}
\multicolumn{2}{c}{ Patients } & \multicolumn{2}{l}{ Controls } \\
\hline Genotype & $\mathbf{n}$ & Mean \pm SD & $\mathbf{n}$ & Mean \pm SD & P-value $^{*}$ \\
\hline LL & 39 & $84.38 \pm 67.20$ & 55 & $127.17 \pm 112.45$ & 0.087 \\
LM & 55 & $74.91 \pm 60.10$ & 50 & $118.21 \pm 124.07$ & 0.085 \\
MM & 8 & $39.18 \pm 45.61$ & 7 & $57.43 \pm 21.61$ & 0.028 \\
LM+MM & 63 & $70.38 \pm 59.37$ & 57 & $110.74 \pm 118.00$ & 0.028 \\
\hline
\end{tabular}

*From Mann Whitney-U test

concluded that there was a statistical significance between PON1 L55M polymorphism and cancer risk $(\mathrm{OR}=1.21,95 \% \mathrm{CI}: 1.04-1.40) \cdot{ }^{37} \mathrm{On}$ the other hand, several studies ${ }^{27-29,35}$ did not demonstrate a significant association between the polymorphism and diverse diseases; this observation is consistent with our results.

Cancer cells produce high amounts of ROS due to the increased metabolic activity, leading to a state known as oxidative stress. ${ }^{38}$ The importance of the association between oxidative stress and leukemia is not currently clear; however, there is evidence that ROS can diffuse into the red blood cells and stimulate the process of lipid peroxidation. It is widely accepted that lipid peroxidation is considered to be involved in the pathogenesis of leukemia. By-products of lipid peroxidation can change the properties of the red blood cell membrane including permeability, fluidity, and membrane enzyme activities and ultimately cell dysfunction or cell death can develop. ${ }^{39}$

In this study, we investigated the role of oxidative stress in the pathogenesis of leukemia by measuring plasma PON1 enzyme activity. When compared with the control group, we found significantly lower PON1 activities in leukemic patients. These lower PON1 activities may show the presence of increased oxidative stress and decreased antioxidant status in circulation; the higher PON1 enzyme activity reduces the risk of developing leukemia. None of the previous studies investigated the plasma PON1 activity in leukemic patients while some studies measured the activity in diverse diseases. The pooled analysis showed that coronary heart disease cases had a 19\% lower PON1 activity than did the controls (RoM=0.81; 95\% CI: 0.74-0.89, $\mathrm{P}<10(-5)) .{ }^{15}$ Similarly, another study show that PON1 was significantly lower in both the familial hypercholesterolaemia and insulin dependent diabetes mellitus cases than in controls $(\mathrm{p}<0.001$ and $\mathrm{p}<0.01$, respectively). ${ }^{16}$ Bansal et al reported that low PON1 activity may be considered as additional risk factor for development of vascular complications in type 2 diabetes mellitus. ${ }^{17}$ Previous studies also suggested that low PON1 activity was associated with an increased risk for many cancer types, such as lung cancer, ${ }^{21}$ laryngeal squamous cell carcinoma, ${ }^{22}$ gastric ${ }^{23}$ and pancreatic cancers. ${ }^{24}$ Our results are supported by these previous studies.

Analysis of PON1 genotypes and measurements of PON1 activities can give a more complete view of PON1 status, because they reflect the combined genetic and environmental effects of PON1. Our data showed that levels of PON1 activity decreased in the patient group compared to the control group for all genotypes. More importantly, PON1 enzyme activity of the individuals with MM genotypes was lower in the patient group than the control group. One study reported that LL variant had significantly higher PON activity than MM variant in both control and diabetic patient groups $(\mathrm{p}<0.05)^{27}$, another study showed that PON 55 MM homozygotes had significantly lower PON activity than did LL and LM genotypes in control and patients with type 2 diabetes mellitus $(\mathrm{p}<0.05) .{ }^{35}$ Similarly, we observed MM variant had significantly lower PON activity than LL and LM variants for two groups. Our results suggest that paraoxonase activity is af- 
fected by PON1 genetic variability in patients with leukemia.

Consequently, the PON1 polymorphism genotype rates do not affect the risk of developing leukemia. However, reduced PON1 enzyme activity and more importantly the combination of PON1 L55M polymorphism with reduced PON1 enzyme activity are associated with the increased risk of leukemia. We think that our result is important and unique. Although PON1 L55M polymorphism is not related with having leukemia risk, PON1 enzyme activity is lower in leukemia patients. This fact shows that PON1 gene expression is lower in leukemia patients. We think that low activity of PON 1 is a leukemia risk factor if it is decreased before catching leukemia. If it is decreasing after catching leukemia, this may be due to the changing hemostatic balance after leukemia. By considering the distribution of leukemia patients in age groups, it is clearly shown that older age is a risk factor of catching leukemia. Our study is the first study evaluating the PON1 L55M polymorphism and PON1 enzyme activity in leukemic patients.

\section{Acknowledgements}

This research was supported by the grants from Research Fund of Mersin University BAP-SBE TB(NEE)2009-8 DR.

\section{REFERENCES}

1. Clapp RW, Jacobs MM, Loechler EL. Environmental and occupational causes of cancer: newevidence 2005-2007. Rev Environ Health 23: 1-37, 2008.

2. Hatcher JM, Pennell KD, Miller GW. Parkinson's disease and pesticides: a toxicological perspective. Trends Pharmacol Sci 29: 322-329, 2008.

3. Singh S, Kumar V, Thakur S, et al. Paraoxonase-1 genetic polymorphisms and susceptibility to DNA damage in workers occupationally exposed to organophosphate pesticides. Toxicol Appl Pharmacol 252: 130-137, 2011.

4. Costa LG, Giordano G, Furlong CE. Pharmacological and dietary modulators of paraoxonase 1 (PON1) activity and expression: the hunt goes on. Biochem Pharmacol 81: 337-344, 2011.
5. Okamura DM, Pennathur S. The balance of powers: Redox regulation of fibrogenic pathways in kidney injury. Redox Biol 6: 495-504, 2015.

6. Jackson MJ, Vasilaki A, McArdle A. Cellular mechanisms underlying oxidative stress in human exercise. Free Radic Biol 98: 13-17, 2016.

7. Bub A, Barth SW, Watzl B, et al. Paraoxonase 1 Q192R (PON1-192) polymorphism is associated with reduced lipid peroxidation in healthy young men on a low-carotenoid diet supplemented with tomato juice. Br J Nutr 93: 291-297, 2005.

8. Levy E, Trudel K, Bendayan M, et al. Biological role, protein expression, subcellular localization, and oxidative stress response of paraoxonase 2 in the intestine of humans and rats. Am J Physiol Gastrointest Liver Physiol 293: G1252-1261, 2007.

9. Aviram M, Rosenblat M, Bisgaier CL, et al. Paraoxonase inhibits high-density lipoprotein oxidation and preserves its functions. A possible peroxidative role for paraoxonase. J Clin Invest 101: 1581-1590, 1998.

10. Durrington PN, Mackness B, Mackness MI. Paraoxonase and Atherosclerosis. Arterioscler Thromb Vasc Biol 21: 473-480, 2001.

11. Adkins S, Gan KN, Mody M, La Du BN. Molecular basis for the polymorphic forms of human serum paraoxonase/arylesterase: glutamine or arginine at position 191, for the respective A or B allozymes. Am J Hum Genet 52: 598-608, 1993.

12. Xiao ZJ, Chen J, Sun Y, Zheng ZJ. Lack of association between the paraoxonase $1 \mathrm{Q} / \mathrm{R} 192$ single nucleotide polymorphism and stroke in a Chinese cohort. Acta Neurol Belg 109 205-209, 2009.

13. Brophy VH, Jarvik GP, Richter RJ, et al. Analysis of paraoxonase (PON1) L55M status requires both genotype and phenotype. Pharmacogenetics 10: 453-460, 2000.

14. Leviev I, Deakin S, James RW. Decreased stability of the M54 isoform of paraoxonase as a contributory factor to variations in human serum paraoxonase concentrations. J Lipid Res 42: 528-535, 2001.

15. Wang M, Lang X, Cui S, et al. Quantitative assessment of the influence of paraoxonase 1 activity and coronary heart disease risk. DNA Cell Biol 31: 975-982, 2012.

16. Mackness MI, Harty D, Bhatnagar D, et al. Serum paraoxonase activity in familial hypercholesterolaemia and insulindependent diabetes mellitus. Atherosclerosis 86: 193-199, 1991.

17. Bansal S, Chawla D, Siddarth M, et al. A study on serum advanced glycation end products and its association with oxidative stress and paraoxonase activity in type 2 diabetic patients with vascular complications. Clin Biochem 46: 109-114, 2013.

18. Ferretti G, Bacchetti T, Saturni L, et al. Lipid peroxidation and paraoxonase-1 activity in celiac disease. J Lipids 2012. doi: $10.1155 / 2012 / 587479$. 
19. Saadat M. Paraoxonase 1 genetic polymorphisms and susceptibility to breast cancer: a meta-analysis. Cancer Epidemiol 36: e101-3, 2012.

20. Balci H, Genc H, Papila C, et al. Serum lipid hydroperoxide levels and paraoxonase activity in patients with lung, breast, and colorectal cancer. J Clin Lab Anal 26: 155-160, 2012.

21. Elkiran ET, Mar N, Aygen B, et al. Serum paraoxonase and arylesterase activities in patients with lung cancer in a Turkish population. BMC Cancer 7: 1-8, 2007.

22. Karaman E, Uzun H, Papila I, et al. Serum paraoxonase activity and oxidative DNA damage in patients with laryngeal squamous cell carcinoma. J Craniofac Surg 21: 1745-1749, 2010.

23. Akçay MN, Yilmaz I, Polat MF, Akçay G. Serum paraoxonase levels in gastric cancer. Hepatogastroenterology 50: cclxxiii-v, 2003.

24. Akçay MN, Polat MF, Yilmaz I, Akçay G. Serum paraoxonase levels in pancreatic cancer. Hepatogastroenterology 50: ccxxv-vii, 2003.

25. Rea IM, McKeown PP, McMaster D, et al. Paraoxonase polymorphisms PON1 192 and 55 and longevity in Italian centenarians and Irish nonagenarians. A pooled analysis. Exp Gerontol 39: 629-635, 2004.

26. Eckerson HW, Wyte CM, La Du BN. The human serum paraoxonase/arylesterase polymorphism. Am J Hum Genet 35: 1126-1138, 1983.

27. Altuner D, Ates I, Suzen SH, et al. The relationship of PON1 QR 192 and LM 55 polymorphisms with serum paraoxonase activities of Turkish diabetic patients. Toxicol Ind Health 27: 873-878, 2011.

28. Arpaci $A$, Görmüs $U$, Dalan $B$, et al. Investigation of PON1 192 and PON1 55 polymorphisms in ovarian cancer patients in Turkish population. In Vivo 23: 421-424, 2009.

29. Yildirim S, Akar S, Kuyucu M, et al. Paraoxonase 1 gene polymorphisms, paraoxonase/arylesterase activities and oxidized low-density lipoprotein levels in patients with migraine. Cell Biochem Funct 29: 549-554, 2011.

30. Antognelli C, Del Buono C, Ludovini V, et al. CYP17, GSTP1, PON1 and GLO1 gene polymorphisms as risk factors for breast cancer: an Italian case-control study. BMC Cancer 9: 115,2009

31. Naidu R, Har YC, Taib NA. Genetic Polymorphisms of paraoxonase 1 (PON1) Gene: association between L55 M or Q192R with breast cancer risk and clinico-pathological parameters. Pathol Oncol Res 16: 533-540, 2010.

32. Hussein YM, Gharib AF, Etewa RL, ElSawy WH. Association of L55M and Q192R polymorphisms in paraoxonase1 (PON1) gene with breast cancer risk and their clinical significance. Mol Cell Biochem 351: 117-123, 2011.

33. Stevens VL, Rodriguez C, Talbot JT, et al. Paraoxonase 1 (PON1) polymorphisms and prostate cancer in the CPS-II Nutrition Cohort. Prostate 68: 1336-1340, 2008.
34. de AguiarGonçalves BA, Vasconcelos GM, Thuler LC, et al NQO1 rs1800566 (C609T), PON1 rs662 (Q192R), and PON1 rs854560 (L55M) polymorphisms segregate the risk of childhood acute leukemias according to age range distribution. Cancer Causes Control 23: 1811-1819, 2012.

35. Agachan B, Yilmaz H, Karaali Z, Isbir T. Paraoxonase 55 and 192 polymorphism and its relationship to serum paraoxonase activity and serum lipids in Turkish patients with non-insulin dependent diabetes mellitus. Cell Biochem Funct 22: 163168, 2004.

36. Chen L, Lu W, Fang L, et al. Association between L55M polymorphism in Paraoxonase 1 and cancer risk: a meta-analysis based on 21 studies. Onco Targets Ther 4:1151-1158, 2016.

37. Hu P, Ma Y, Zhang L, Ma S. PON1 L55M polymorphism might contribute to the risk of cancer. Panminerva Med 59:107-113, 2017.

38. Al-Gayyar MM, Eissa LA, Rabie AM, El-Gayar AM. Measurements of oxidative stress status and antioxidant activity in chronic leukaemia patients. J Pharm Pharmacol 59: 409-417, 2007.

39. van Ginkel G, Sevanian A. Lipid peroxidation-induced membrane structural alterations. Methods Enzymol 233: 273-288, 1994.

\section{Correspondence:}

Dr. Nazan ERAS

Mersin Üniversitesi Tip Fakültesi

Tibbi Genetik Anabilim Dali

Ciftlik Köy Kampüsü

33343, MERSIN / TURKEY

Tel: (+90-324) 3610001

Fax: (+90-324) 3610015

e-mail: nazaneras@gmail.com 